\title{
Restoration and Rehabilitation of world heritage Site of Chupan Church
}

\author{
Shirin Darvish Rohani \\ Ph.D student of Urban Planning and Design of Tehran Azad University \\ shirinrohani@yahoo.com
}

\section{KEY WORDS: CHUPAN CHURCH, HOVVI CHURCH, NAKHIRCHICHI CHURCH, WORLD HERITAGE SITE OF ARMENIAN MONASTERIES IN IRAN, HISTORICAL EVIDENCE OF ARMENIAN IN JOLFA CITY OF IRAN}

\begin{abstract}
:
Church of Chupan is located in Jolfa cityin north of Iran and is laid at south side of Arax River. Built of the church traced back to $14^{\text {th }}$ to $15^{\text {th }}$ century and the time when Armenians were inhabited in the region.

Chupan church had been inscribed at World Heritage List of UNESCO under no 1262 in 2008, as one of the five churches of "Armenian Monasteries of Azerbaijan province of Iran" dossier. As it is located at a religious and tourism road of Darresham and each year most of Armenian from all over the world visited the church as a part of a religious ceremony, also as the same church on opposite side of the Arax in Republic of Nakhchivan is completely destroyed between 1998 -2002 and the church is the only existing evidence of these two couple church, the restoration and rehabilitation of chupan church is very important. Because of very bad statues of structure stability and long-term neglect of the conservation and preservation of the building, restoration and rehabilitation of the church in the earliest was necessary.
\end{abstract}

Restoration of this church was my MA degree thesis and now as a Ph.D student in field of urban design and planning student, I am working on the next step which is to revitalization and rehabilitation of the church.

\section{GEOGRAOHICAL POSISION OF THE CHUPAN CHURCH:}

Church of Chupan is located at $3 \mathrm{~km}$ far from Jolfa city in Western Azerbaidjan province of Iran (Islamic Republic of) at geography coordination of $38.97652 \mathrm{~N}$ and $45.57555 \mathrm{E}$. It is laid at south side of Arax River.In current structure of the area; it is in the vicinity of the main road of Darresham to Jolfa city that due to the numerous historical monuments is known as a tourism valley.

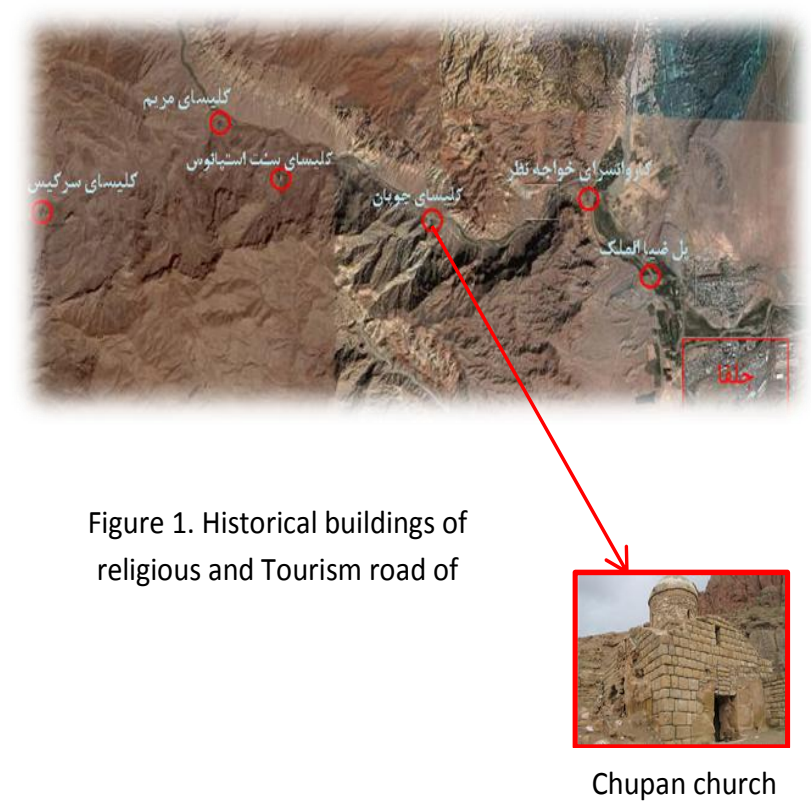

\section{REASON OF NAMED AS “CHUPAN CHURCH” :}

The church is called as Chupan church between locals and also in official documents which means Shepherd church, as it is belongs to Armenian religious minorities of Iran is also known as Hovvi by meaning of Shepherd church in Armenia. Also the main language of residents of surrounded area is Turkish and they call Chupan church as Nakhirchichi which means Shepherd church in Turkish too.

There are three possibilities as the reason of the church name :first it named Chupan as it is belongs to Shepherd during grazing time, also as the Jesus Christ ( peace be upon him) is known as Shepherd for his people this church named as Church, and the last one is goes that limited number of Armenians called church as "Andre Verdi" that means son of Andre, so it can be a small church that is dedicated to Andre's son.

The Chupan is a small church without any complexity in architecture or even magnificent ornaments and that makes it more accurate to believe that it is built in order that Shepherd of Armenian villages while are at grazing out of the village , prayed and did religious practices in this small place with simple architecture. 


\section{HISTORY OF THE CHURCH :}

There is no accurate documentation abut date of main built of the church but due to comparative study with other churches in the area from the point of architectural, functional and materials similarities, it traced back to 14 th to 15 th century.

\section{CHUPAN CHURCH AS WORLD HERITAGE SITE OF UNESCO:}

Chupan church had been inscribed at World Heritage List of UNESCO under no 1262 in 2008, as one of the five churches of "Armenian Monasteries of Azerbaijan province of Iran" dossier.

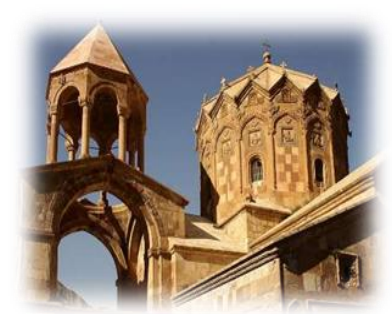

St. Stephanous monastery

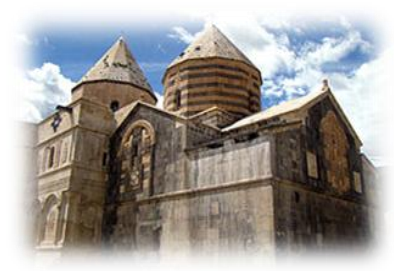

St. Taddeous monastery

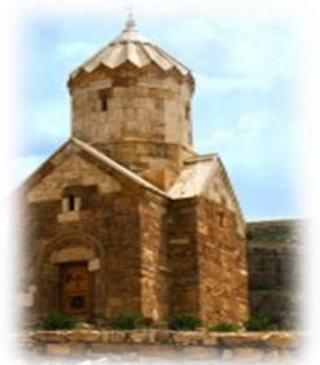

Dzor Dzor church

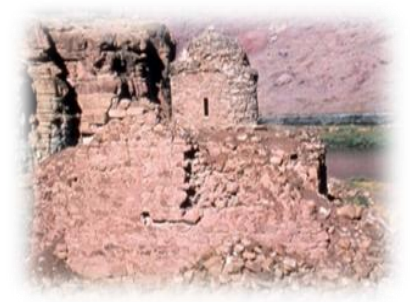

Chupan church

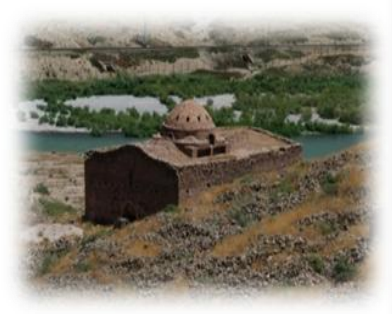

Maryam church
Figure 2. Churches of Armenian Monasteries of Iran

\section{IMPORTANC OF RESTORATION REHABILITATION OF CHUPAN CHURCH:}

AND

There are several important aspects make it important monument, not just for Iranian but as world heritage site, for all human been.

* First of all, the church is located at a religious and tourism road of Darresham. Each year ,in early of July, most of Armenian people from Iran and all around the world come
The St. Stephanous monastery is not located far from Chupan church, (15 km far) and pilgrimages, first visit Chupan church and then go to St. Stephanous monastery.

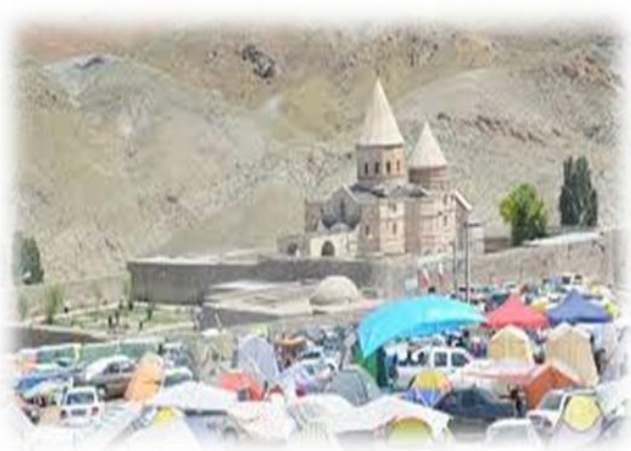

Figure 3. Religious ceremony of Armenian next to Taddeous Monastery

* In the other hand the church is located at southern side of Arax River. In the past, there was two similar churches by the name of Chupan, one of them were located in southern side in Iran and the other on northern one in Azerbaijan republic.

Unfortunately after independency of Republic of Nakhchivan, between 1998 -2002 the church on northern site and its historical cemetery was completely destroyed. That made the current Chupan church in Iran the unique one and shows the respect to other religious believe in an Islamic country of Iran.

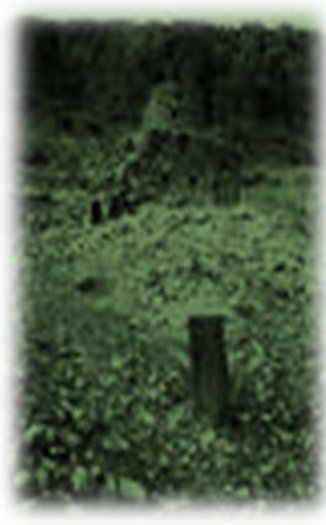

Figure 4. Chupan church in Republic of Nakhjavan. Before destroyed

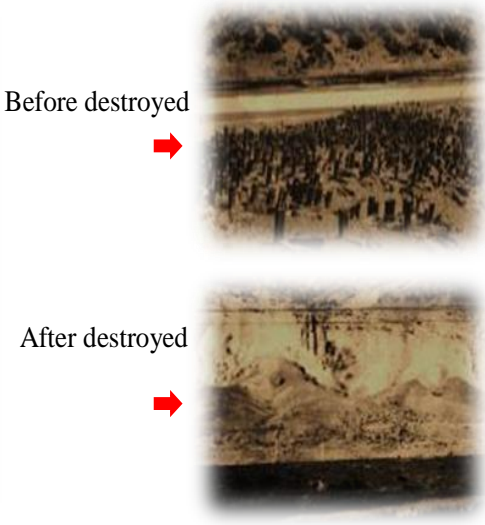

Figure 5. Cemetery of Chupan church, Republic of Nakhjavan
* As the third aspect that make monitoring of this church very importance is Lack of care and attention to this site for many years that cause it in a serious situation which need immediately conservation and restoration. 
For especially religious ceremony (that takes one week) and visit St. Taddeous monastery and St. Stephanous monastery, as pilgrimages.

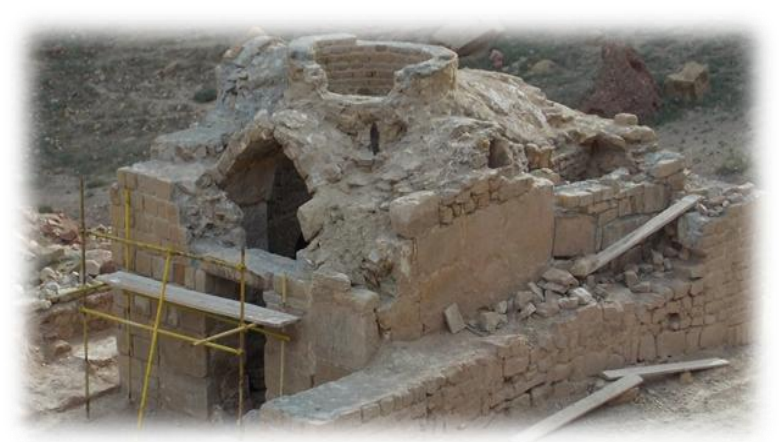

The church chupan from south western façade before 2014

All these issues made the site priority of Iranian Cultural Heritage, Handicrafts and Tourism Organization to be under restoration.

\section{PLAN AND ARCHITECTURE OF THE CHURCH:}

The church is located on a smoothed hillock the site is enclosed from 3 sides by stone retaining ramparts that each one has different height and even it is clear that the current appearance are built in different periods (because of different restoration in different years ).it seems the northern wall had never been completed.

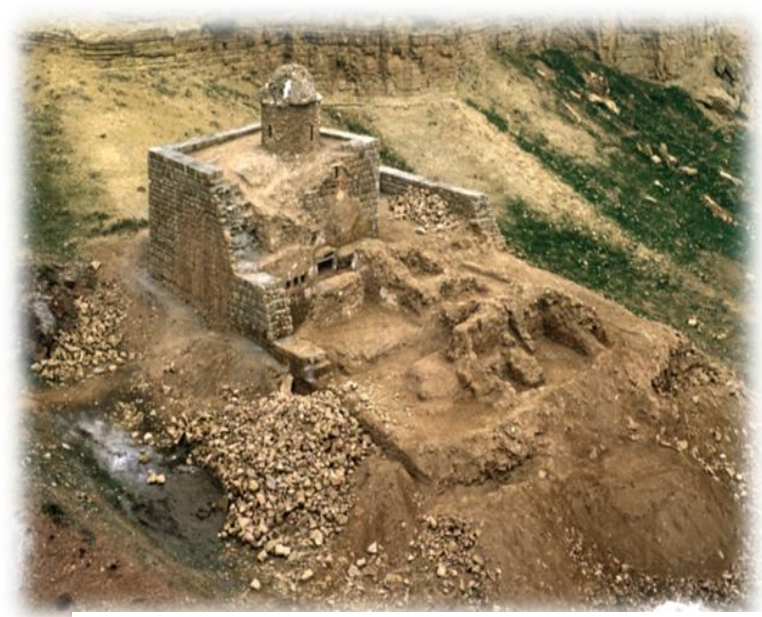

Figure 6. Ramparts of Chupan church.befor restoration of 2014

In the past there were remnants of residential and utility buildings but unfortunately there are completely vanished now. The general entrance of the site opens from the southern rampart.The church used to be rectangular outwardly $(5.68 \times 7.37$ metres), representing a domed cruciform building inwardly.It has a circular tambour and a conical spire borne by pendentives and 4 stone arches, which rest on 4 angular wall pylons.

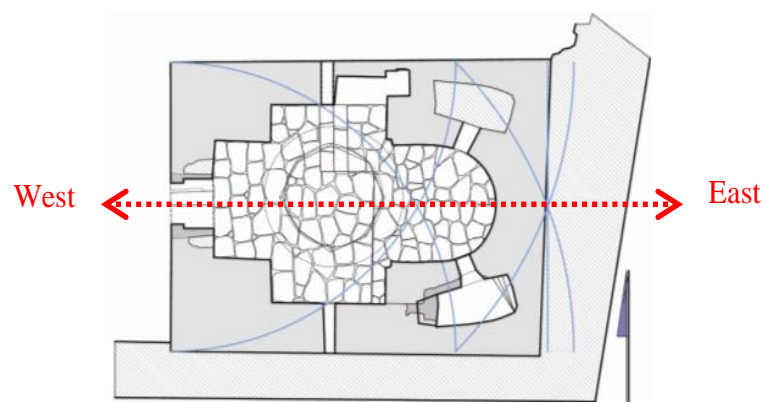

Figure 7. Chupan Church plan

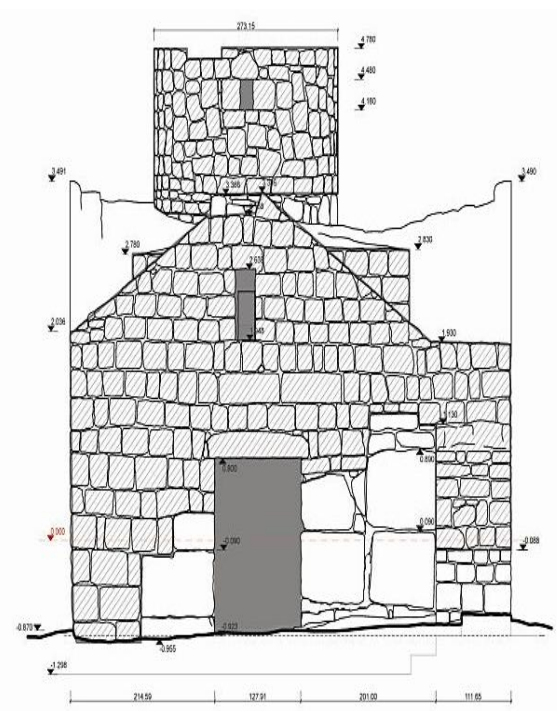

Figure 8. Western facade

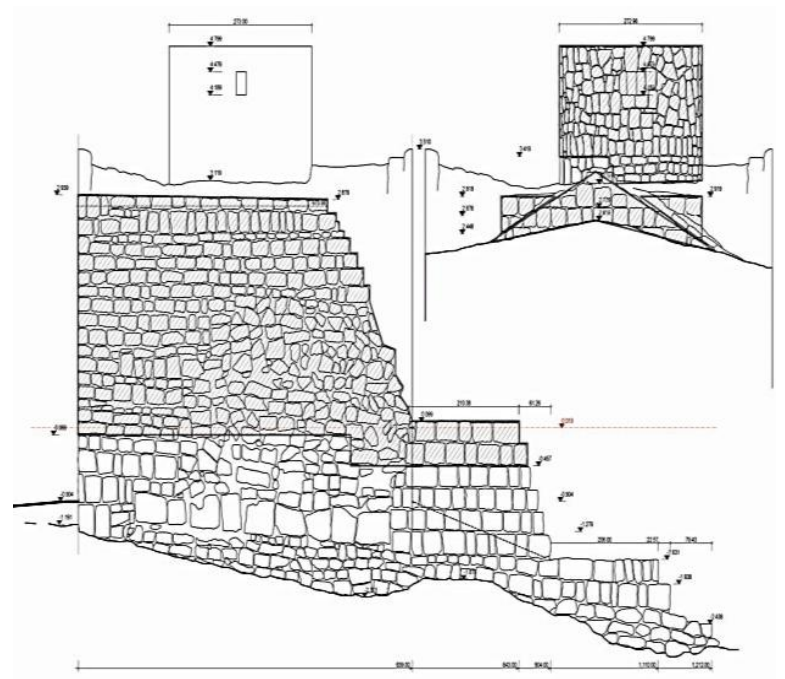

Figure 9. Eastern 


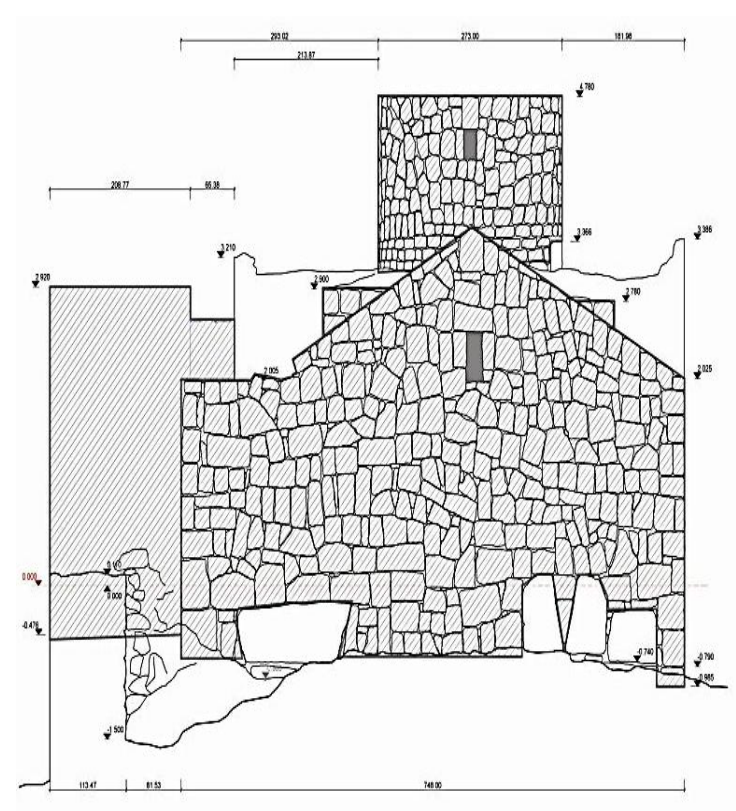

Figure 10. Northern facade

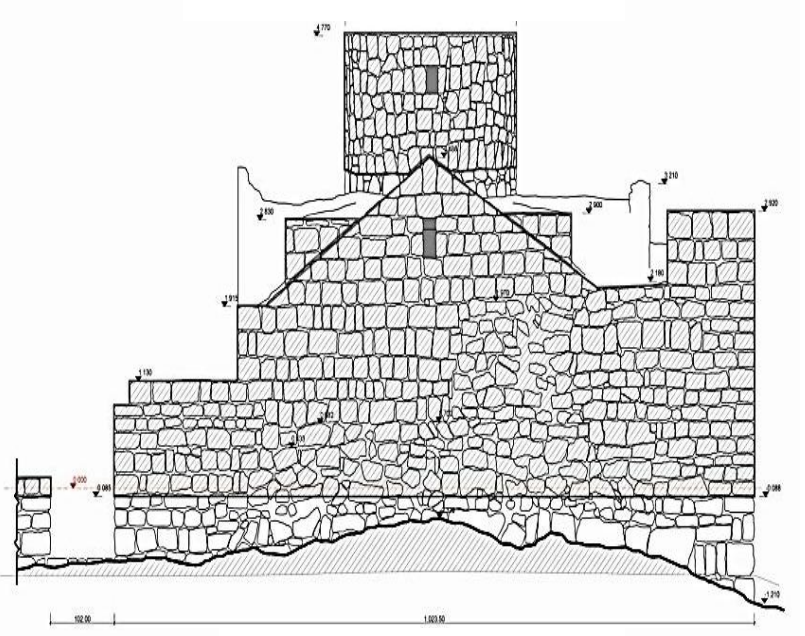

Figure 11. Southern facade

\section{PREVIOUS RESTORATION:}

In the past during two times some restoration and conservation had been taken at the church but unfortunately the both times, the activities are taken without planning, feasibility study and even full study of the church, also the restoration were taken by not educated and expert masters and were done by local authorities without knowledge of restoration. That cause more damaged on the church and has caused harm on integrity and authenticity of Chupan church.in some parts it changed the forms of main architecture, (as the one was taken on dome of the church) or not suitable materials were used, also overload is a serious problem that is happened during these restoration activities.

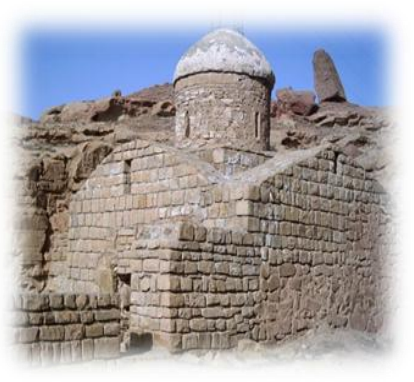

After first time restoration

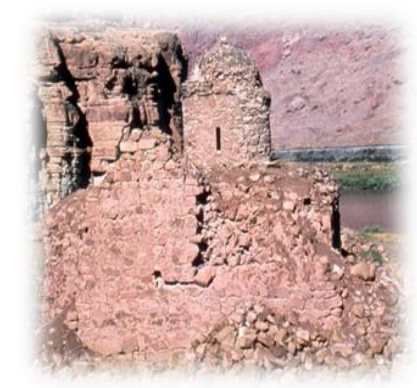

The original structure
Figure 12. Previous restoration
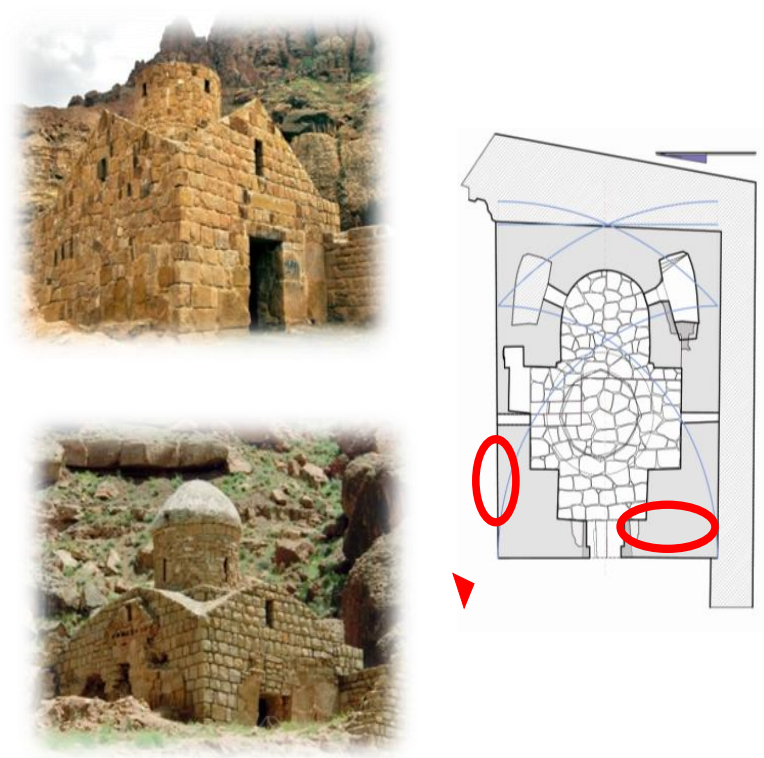

Figure 13. Architectural changes in previous restoration

\section{RESTORATION PLAN OF CHUPAN CHURCH:}

After a full geographical, historical, architectural and technical study of the church, the current situation of the church had been mapped and documented. According to results of studies and comparative study also due to budget and time and other resources, some alternative plans were proposed. During chosen restoration plan, there main activities had been taken:

* Some parts that were incorrectly restoration before had been destroyed and replace by correct one, such as the dome.

* In the case that the main stones were not fund they replaced by accurate local ones.

* Humidity problems were solved by replaces new materials.

* The missing parts of the architecture were rebuilt on results of feasibility study and evidence.

* The whole building were Strengthening. 
* Overheads problems that were cause by collecting trash during a long time, especially on the dome, were solved by collecting trash.

* The materials (stones) were place at incorrect position and the ones that were not belongs to the main structure of the church and had been used improper during past restorations were replaced.

* Some previous wrong restoration caused overheads problems, these parts were destructed and rebuilt correctly.

* Determination core zone, buffer zone and landscape one.

* Some damage that has been done by mankind to find antiques, were restoration.
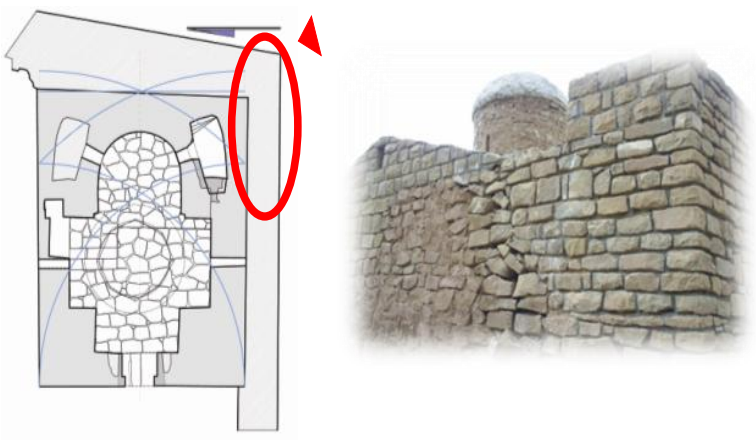

Figure 14. Incorrectly restoration
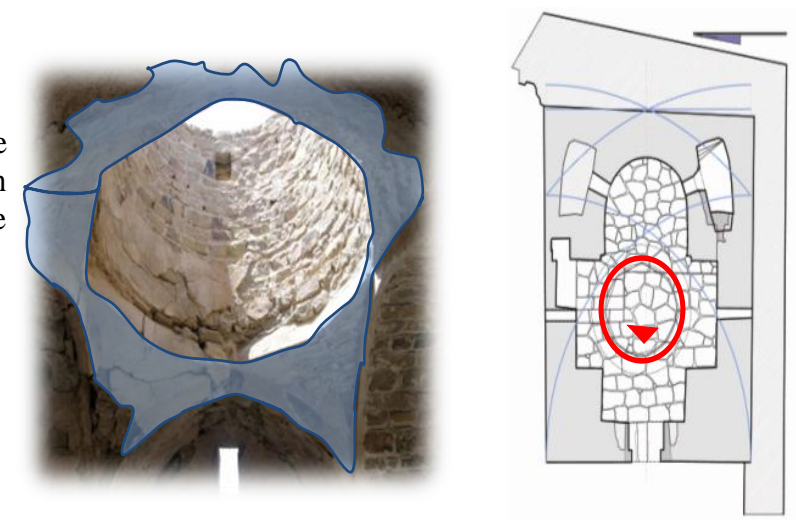

Figure 17. Humidity disaster
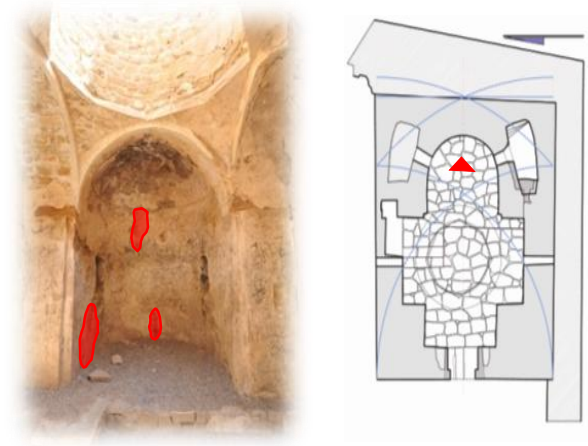

Figure 18. Mankind disaster
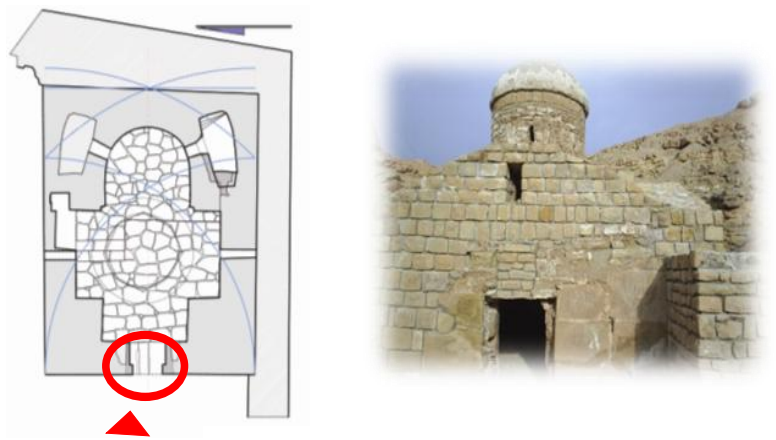

Figure 15. Incorrectly materials
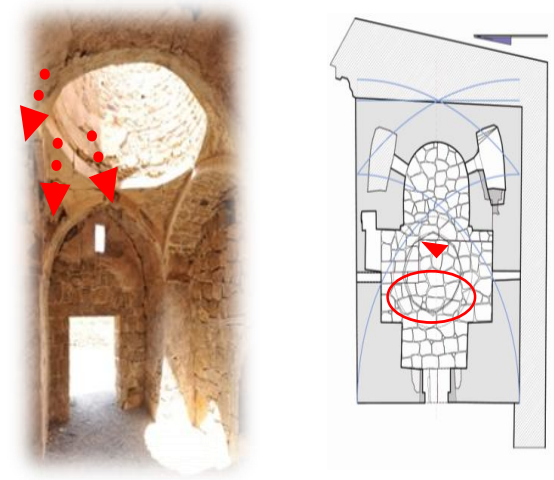

Figure 19. Overheads problems, because of previous wrong restoration
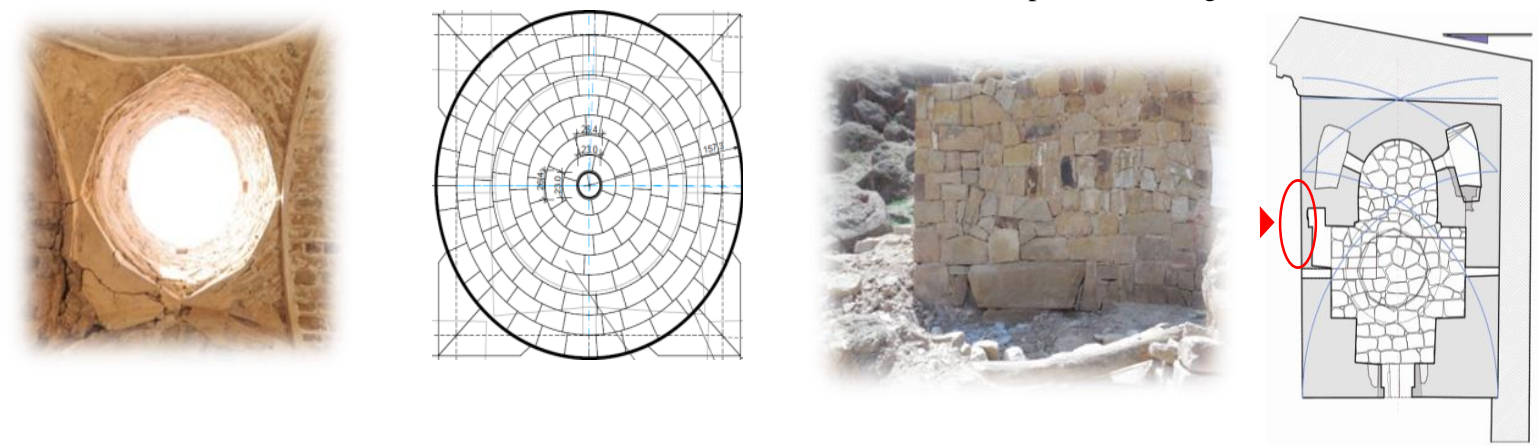

Figure 16. Completely destroyed of the dome

Figure 20. Incorrectly replace of stone 

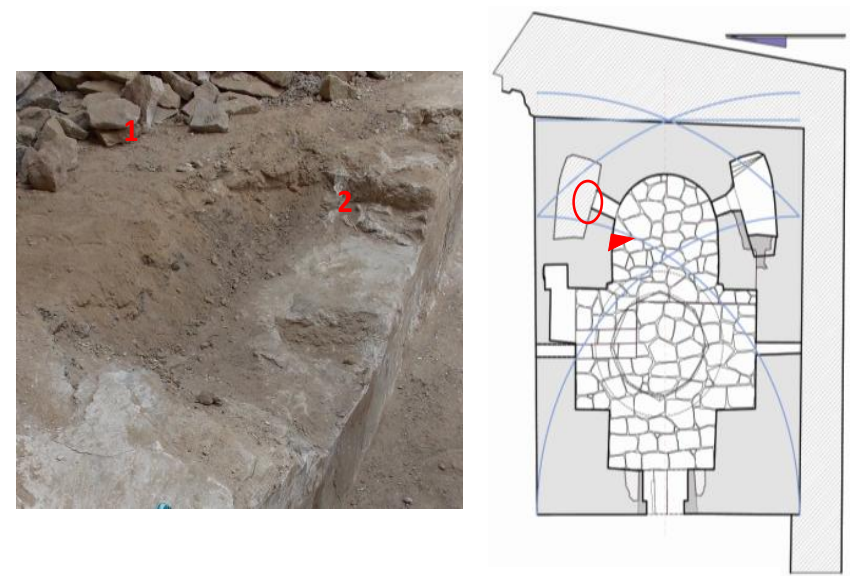

Figure 21. Overheads problems.because of collecting trash

1. before restoration floor

2. Original floor

The restoration project of Chupan church was a complicated two years activity that was my MA degree Thesis and now as a Ph.D student in field of urban design and planning student, I am working on the next step which is to revitalization and rehabilitation of the church.

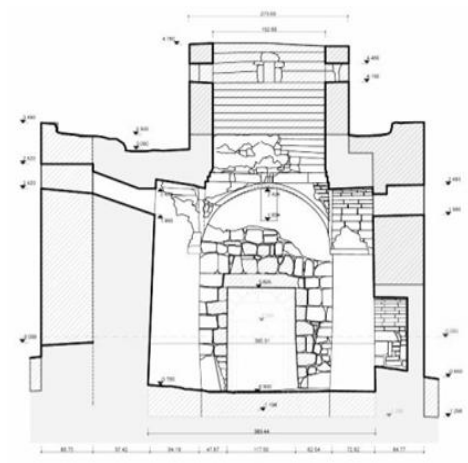

Figure 22. Western façade of the church .befor

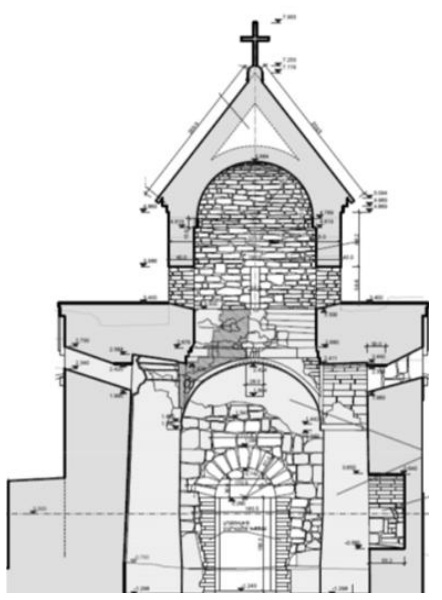

Figure 23. Western façade of the church .After

\section{REHABILITATION PLAN OF CHUPAN CHURCH:}

After restoration, the next step is to revitalization and rehabilitation of the church. There are several issues that should be focused for this part:

* Being as a religious buildings that is respectful by Armenian

* Having close relation with the Armenian historical village of Darresham

* Dependency to intangible heritage of residents of Jolfa

* Surrounded by valuable natural heritage and impotency of its cultural landscape

* Being in tourism road of Jolfa to Darresham

The above facts make reuse of the site as a sensitive and importance, because in addition of tangible heritage as a historical buildings, the intangible values that connect the church to Armenians' life from 14th century up to now ,as a religious place, need special notice. In order to give back life and usage to this building, it is very important to respect to religious role of the site.

According to all weakness, Strengths, opportunity, Threats and opportunity of the site in all aspects of architecture , needs of the region, geographical situation, tourism studies, religious limitation, state rules and Iranian Cultural Heritage, Handicrafts and Tourism direction, legally and local laws,...the best new usage of the church is its original one as a church.

Also it is very important to give information about the importance of the church and the measures taken in its restoration by local mass media, Information boards on routes leading into the church, having Brochures, catalogs and other kind of Information documentation, establishing website for the church and having link to it from tourism and cultural related website to it, Set up information desk and a guard with enough information about the church is very important.

\section{REFRENCES:}

* Darvish Rohani,Shirin., 2014 Restoration and Rehabilitation of World Heritage Site of Chupan Church, thesis of MA degree in field of restoration and rehabilitation of historical buildings and sites, Tehran Azad University publication, Tehran. Iran.

* Jokilehto, Jukka. , 1993, Management Guidelines for World Cultural Heritage Site, ICCROM publication, Rome. Italy.

* Anderanic,Houman., 2004, History of Armenian of Iran, Publication of Iranian Cultural Heritage, Handicrafts and Tourism organization, Tehran. Iran.

- Malekmian,Lina., 2000, Armenian Church of Iran, Publication of Iranian Cultural Heritage, Handicrafts and Tourism organization,Tehran. Iran. 
The International Archives of the Photogrammetry, Remote Sensing and Spatial Information Sciences, Volume XL-5/W7, 2015 25th International CIPA Symposium 2015, 31 August - 04 September 2015, Taipei, Taiwan

* Aivazian,Argam. , 2004, Inscription Heritage of Nakhchivan, Jogha Publication, Yerevan. Armenia.

* Armenian of Iran booklet, 2001, International Center for Dialogue among Civilizations Publication, Tehran. Iran.

* Restoration and Revitalization Document of cultural and historical monuments, 1388, Rehabilitation and Revitalization of historic buildings Fund publication, Tehran. Iran. 